\title{
REVIEW
}

\section{Spinal institutions in post-Revolutionary France}

\author{
M-F Weiner and JR Silver \\ Emeritus Consultant at the National Spinal Injuries Centre, Buckinghamshire, UK
}

\begin{abstract}
Study design: Literature review.
Setting: Europe with special reference to France.

Objectives: To describe the first known orthopaedic rehabilitation units founded in France in the first half of the nineteenth century for the treatment of spinal curvature and deformity and analyse their impact on the future provision of rehabilitation treatment in Europe.

Conclusion: Despite the pioneering work of a few French orthopaedic surgeons and doctors, no longlasting legacy remains from the establishment of innovative and holistic institutes for the treatment of spinal curvature and deformity as early as the 1830 s.

Spinal Cord (2010) 48, 274-284; doi:10.1038/sc.2009.173; published online 26 January 2010
\end{abstract}

Keywords: spinal curvature; scoliosis; orthopaedic institute; France

\section{Introduction}

A major advance in the development of medicine in the latter half of the twentieth century was the opening of designated rehabilitation units. This was a consequence of the Second World War. Soldiers who in the First World War would have died of their wounds were treated immediately by specialized teams of surgeons and therefore survived, but were severely disabled and needed further rehabilitation to achieve independence.

These rehabilitation units followed different patterns. In the United Kingdom, they were attached to military, Emergency Medical Services or Ministry of Pensions hospitals. The responsibility for rehabilitation rested with the treating surgeons. Physical medicine consultants were rare and had a secondary role. In contrast, in continental Europe and in the USA, free-standing rehabilitation units were erected to treat all forms of disability, including injuries of the nervous system. By the end of the Second World War, there were seven convalescence hospitals in the USA dedicated to the rehabilitation of servicemen. Subsequently, patients with spinal deformities were congregated in designated spinal units. ${ }^{1}$

It was surprising that 150 years before this, there were at least seven orthopaedic institutes in France providing a holistic long-term residential care for the treatment of spinal deformity. Some of these units were described by Keith $(1919)^{2}$ and Le Vay $(1990),{ }^{3}$ but there has been no comprehensive evaluation documenting their origins, the facilities, the types of treatment administered or their

Correspondence: Dr JR Silver, Emeritus Consultant, Stoke Mandeville Hospital, 8 High Street, Wendover, Buckinghamshire, HP22 6EA, UK.

E-mail: jrussellsilver@btconnect.com

Received 9 September 2009; revised 12 November 2009; accepted 15 November 2009; published online 26 January 2010 influence on the development and recognition of orthopaedics and rehabilitation as independent specialities.

There was a rich literature on orthopaedic treatment in France at the beginning of the nineteenth century. Seven orthopaedic units dedicated to the treatment of spinal deformity are evaluated; five in Paris, ${ }^{4-8}$ one in Lyon, ${ }^{9}$ one in Montpellier ${ }^{10}$ and reference is made to a satellite unit in Angers. ${ }^{5}$ Rather than describe them individually, a comparison of these units and an analysis of the political and scientific climate prevailing in nineteenth century France provides an insight into how orthopaedics became accepted as a speciality.

\section{The units (see Table 1)}

\section{Historical background}

Jean André Venel (1740-1791), a native of Switzerland studied medicine at Montpellier. He founded the World's first orthopaedic institute at Orbe, Switzerland in 1780, in a ruined collection of buildings, which he restored. It had a workshop, a therapeutic bath, a classroom and patients with spinal deformities were treated there for many years with a combination of bracing, traction and massage, setting a pattern for future units. ${ }^{3}$ It is thought that François Humbert (1776-1850) established the first orthopaedic unit in France in Bar le Duc in 1817, where he treated cases of scoliosis using a combination of extension beds and chairs, but it was isolated from universities and hospitals. ${ }^{11}$

\section{Dates of foundation and origin of the units}

All private units emerged between 1820 and 1840. Pravaz inherited a unit from his mother in law who previously ran a 


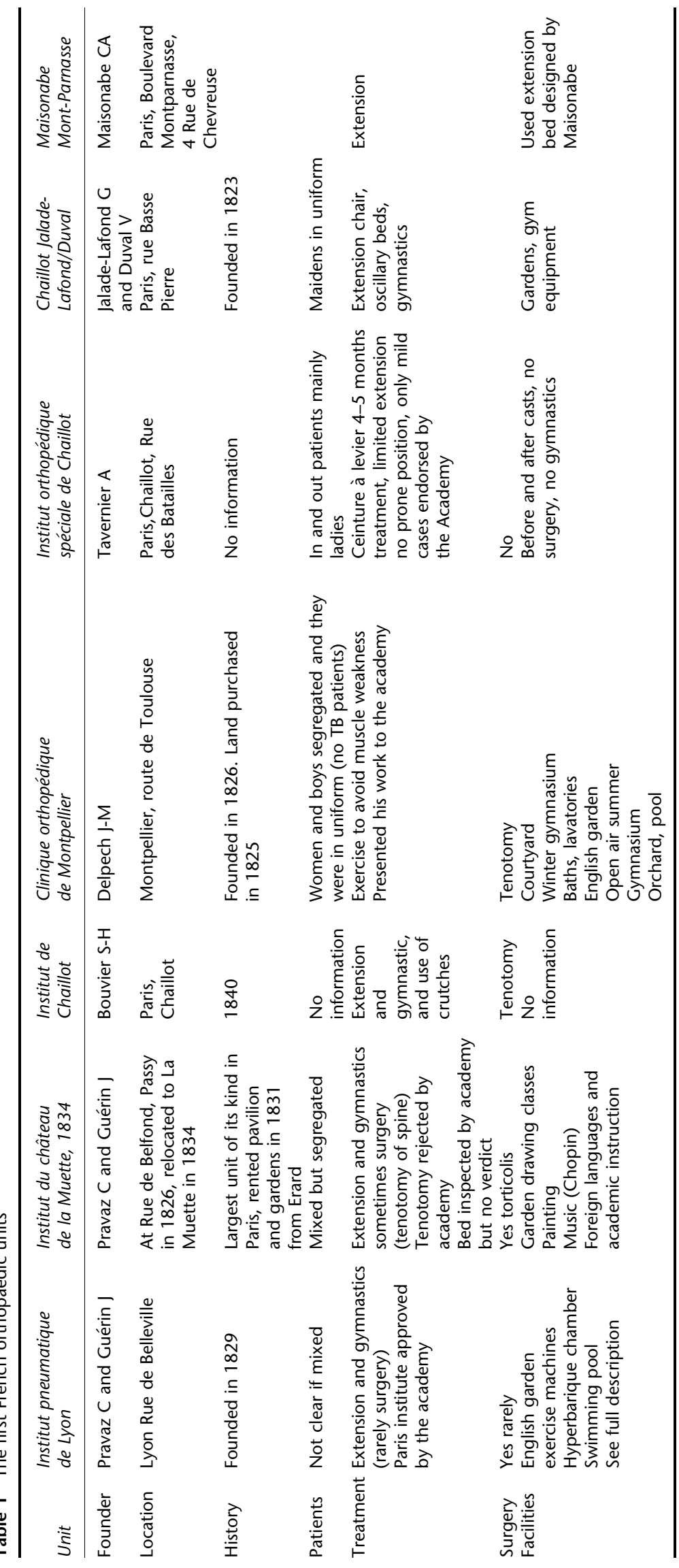


girls' boarding school on the premises and Bouvier took over his Paris institute from a patient of Heine's. ${ }^{3}$ The other units were founded de novo and were not based on existing hospitals or spas. The largest were the Institut du Château de la Muette, founded by Pravaz and Guérin in Paris, Pravaz's Lyon institute and Delpech's Clinique orthopédique de Montpellier. Guérin rented the Château de la Muette, whereas Delpech personally bought 6 acres of land outside Montpellier to have the unit purpose built. The founders were innovative, progressive and often worked in partnership. Guérin worked with Charles Pravaz and Tavernier worked with Hossard, an orthopaedic-mechanic based in Angers. Jalade-Lafond worked with his nephew Dr Duval. All the units were founded by qualified doctors, most of whom had trained in Paris, with the exception of Hossard, who was an orthopaedic-mechanic.

\section{Position of the units}

Four of the five Parisian units were situated around the Bois de Boulogne, an affluent and pleasant area providing sylvan surroundings for residential care. The Montpellier unit was situated among orchards just outside the city in the countryside and in Lyon, Pravaz's unit stood on a hill alongside a river. The units were close to the municipal hospitals and the universities where their founders held appointments and gave lectures, thus facilitating cross fertilisation of ideas between different institutions.

\section{The founders (background, qualifications, history, publications, appointments, associates)}

The founders of the units came from privileged backgrounds. Pravaz and Maisonabe followed the family medical tradition. Three held hospital appointments, Bouvier and Guérin worked at the Hôpital des Enfants Malades and Delpech was professor of surgery and chief surgeon at the Hôpital St Eloi, in Montpellier. Bouvier, Delpech, Guérin, JaladeLafond, Maisonabe and Pravaz all lectured on the subject of orthopaedics and published extensively in scientific journals and books presenting their work to the 'Académie des Sciences' and their peers. Guérin was the editor of La Gazette Médicale de Paris, the oldest medical journal in France (see Table 2). ${ }^{12}$

Nineteenth century Paris was the centre of scientific research and teaching. Bouvier worked with Duchenne de Boulogne, the eminent neurologist and physiologist, and Delpech had worked with Dupuytren in Paris, the premier surgeon of the time.

\section{The patients}

Medical knowledge at that time was such that patients with traumatic injuries to the spinal cord did not survive the initial injury. There were three patients described by Delpech in 'De L'Orthomorphie' (see cases 1, 2 and 3 below), one with a 'tuberculous' spine who developed paraplegia, a second with a severe kyphosis who developed paraplegia and a third patient suffering from tuberculosis of the cervical spine who after a careless transfer died instantly. ${ }^{10}$

The units were mainly dedicated to the treatment of spinal deformity, especially in young women, although Guérin and Delpech had segregated facilities for men. Tavernier and Jalade-Lafond's units were exclusively for women. As most units treated cases of only idiopathic scoliosis, Guérin in his advertising pamphlet for 'l'Institut de la Muette' mentions cases of scrofulous disease of the spine being successfully treated. ${ }^{4}$ In a similar pamphlet, Pravaz in Lyon mentions Potts' disease, club foot, hip luxation and other diseases of the joints. Delpech and Bouvier also treated club foot. ${ }^{9}$

Treatment was residential, but Tavernier offered outpatient facilities to reduce cost, and claimed that he could treat patients in a matter of months not years like his competitors. $^{5}$

Case 1: the bone projection compressed the spinal cord in a most dangerous manner. One can, therefore, see that the 'tuberculosed' vertebra can be cured, but at the same time the lower limbs become paralysed forever.

Case 2: a man of 38 years died after refusing to rest a single moment after long and acute pain associated with the initial deformity. He developed a near complete paraplegia... as the deformity increased, he could only walk with crutches. Despite advice from parents and doctors, he carried on moving and suddenly he suffered further compression of the cord and the paralysis became more severe, this time involving the bladder and the rectum. It was followed by fever that travelled to the paralysed limbs causing rapid death.

Case 3: a patient suffering from cervical tuberculosis, being carried carelessly by a male nurse during transfer and the weight of his head was sufficient to cause death. (He suffered from an acute atlanto-axial dislocation.)

\section{The facilities}

The units offered ancillary facilities not directly related to the management of the spine, such as tuition in music, dancing, swimming and formal academic lessons. Jalade-Lafond, Pravaz and Delpech's patients wore specially designed uniforms. Advertising pamphlets describe in detail the Institut orthopédique du Dr Tavernier, Guérin and Pravaz's Institut orthopédique de Paris based at the Château de La Muette (see Figure 1) and Pravaz's Lyon Institute. Delpech's Clinique Orthopédique de Montpellier is accurately described and illustrated in his book De l'Orthomorphie, published in $1828 .^{10}$ The last two institutes boasted beautiful 'English' gardens, extensive grounds, gymnastic equipment, indoor and outdoor gymnasiums, a swimming pool, an orchard and boarding quarters with segregated areas for boys and girls. Delpech's patients could continue their education by attending academic lessons, drawing, painting, dancing, music and singing lessons (see Figure 2). Chopin taught piano at the Château de La Muette, which is perfectly plausible because Guérin rented the premises from a Mr Erard, a piano manufacturer who would most certainly have been acquainted with the acclaimed pianist., ${ }^{43}$ The Lyon 


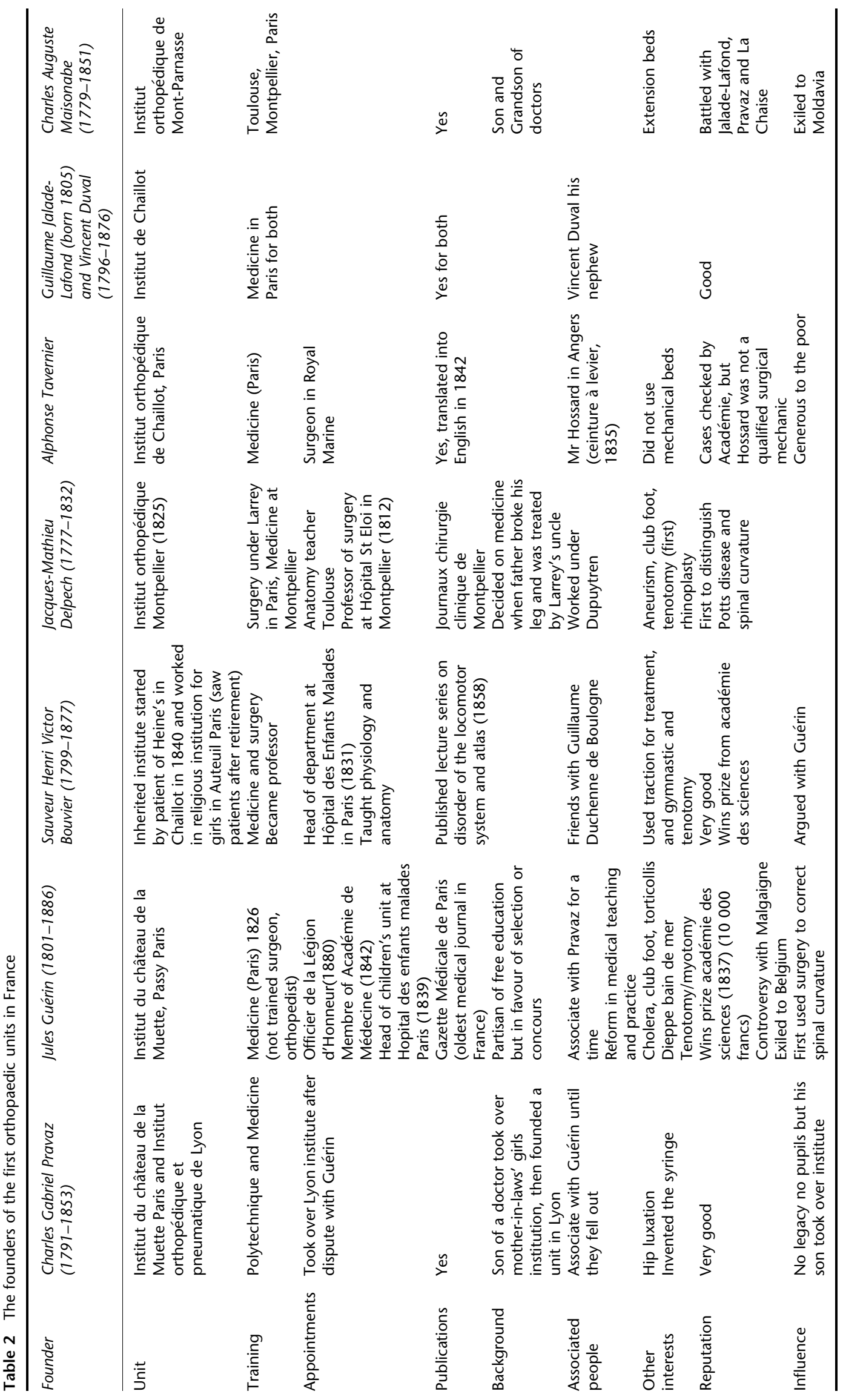




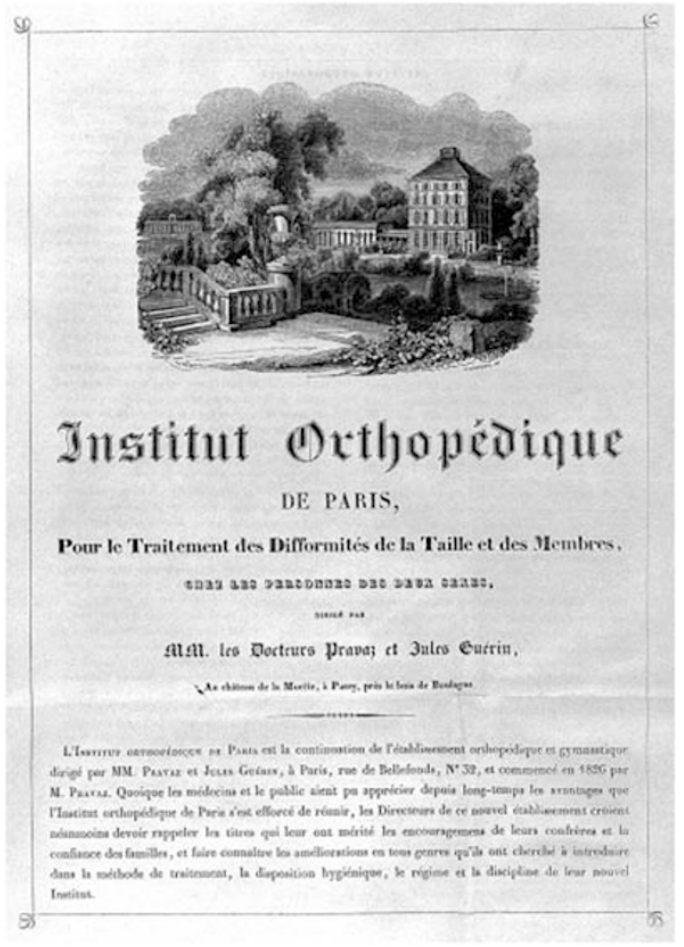

Figure 1 The front page of the advertising pamphlet for Pravaz and Guérin's Institut de la Muette situated near the Bois de Boulogne in Paris and surrounded by beautiful landscaped gardens, c. 1837

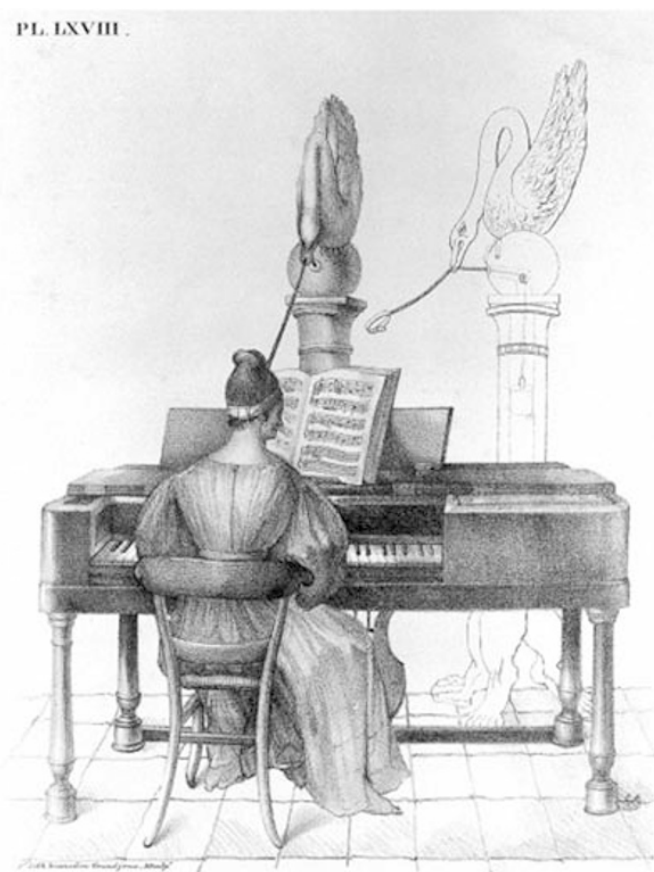

Figure 2 Even when playing the piano, the emphasis was on correcting the faulty posture of young ladies being treated at Delpech's Montpellier Institute. Illustration taken from Delpech's De I'Orthomorphie par Rapport à l'éspèce Humaine, 1928.

unit boasted extensive hydrotherapy facilities, hot and cold baths, compressed air chambers and electrical equipment.

\section{Treatments used (operative and non-operative)}

\section{Historical background}

The first description of scoliosis and its treatment was by Hippocrates. He recognized that it could affect people in good health and had many causes, such as bad posture and the attitude that people adopted. At that time, treatment was mainly by exercise. There was little progress in treating the condition in classical times apart from abandoning forced correction of the deformity. Francis Glisson (1597-1677) was the first to give a description of rickets. ${ }^{14}$ He believed spinal curvature was because of the uneven bone growth and he advocated the use of suspension with a sling (named after him) to correct the deformity in children. Nicholas Andry (16581717) accepted the classic views and placed deformed children in chairs to keep their backs straight. The Dutch surgeon Hendrik van Deventer (1651-1724) initially worked in obstetrics and noticed that an abnormal pelvis could interfere with delivery. Many of these cases were associated with scoliosis and the study of this condition led him to devote much of his career to the treatment of spinal deformity. In his orthopaedic institute in Boorburg, he suspended the patients by placing bands under their armpits and used gravity to correct the spinal curvature. ${ }^{15}$ In Germany, Samuel Thomas von Soemmerring (1755-1830) treated fractures and dislocations of the spine and gave the first description of a case of achondroplasia. ${ }^{16}$ Venel treated scoliosis in his Orbe institute. Methods of treatment included suspension, traction and gymnastics. In France, in the eighteenth century, Jean Pierre David (1737-1784) described caries of the spine leading to deformity. He advocated natural movement when the inflammation had resolved. ${ }^{17}$ The physician Theodore Tronchin (1709-1781) published little but was very critical of the various treatments prevalent at the time. He advocated breast feeding and was concerned that deformity of the spine could be caused by swaddling infants too tightly. ${ }^{18}$ By the turn of the eighteenth century, there was great interest in scoliosis in the United Kingdom, the German speaking world and France. In England, Robert Chessher (1750-1831) treated patients in their own homes by relaxing the contracted muscles and applying splints. Edward Harrison (1766-1838) treated patients through exercise to relax tight muscles and ligaments, producing remarkable results, possibly on people suffering from hysterical mal position of the vertebra; he founded a private spinal institute. Verral (d. 1843) also set up a small private institute, but overall, treatment was limited and fragmented. In Würzburg, Johann Georg Heine (1770-1838), an orthopaedic mechanic who successfully adapted and used Venel's extension bed, renaming it 'the Würzburg bed', founded the country's first orthopaedic institute in 1816. ${ }^{3,19}$ Joseph Clement Tissot (1747-1826) thought that deformity started at birth as a result of disease, such as rickets or bad posture, and it could be corrected by exercises and games. ${ }^{20}$ In 1845 , Werner set up an 'Institut Gymnastique Orthopédique Ducal in Dessau for the treatment of scoliosis. $^{21}$

Before John Shaw (1792-1827), it was thought that scoliosis was because of the unilateral spasm of the spinal muscles but when the patient stood up, spasms ceased which implied that scoliosis was because of muscle weakness. It was 
believed that patients should be treated by rest on one side, but prolonged rest in itself could be injurious and lead to muscle weakness and atrophy, so graduated exercises were prescribed.

Shaw critically evaluated and discussed the existing treatment thus:

'First, act upon the spine so as to alter the present position of the vertebrae, and consequently of the ribs and shoulders. Secondly, keep the vertebrae in their new and improved position. The third and most essential object is to bring the muscles of the back into such a condition that they will after a certain time, be capable of the spine in its natural position without the aid of any artificial support. ${ }^{22}$

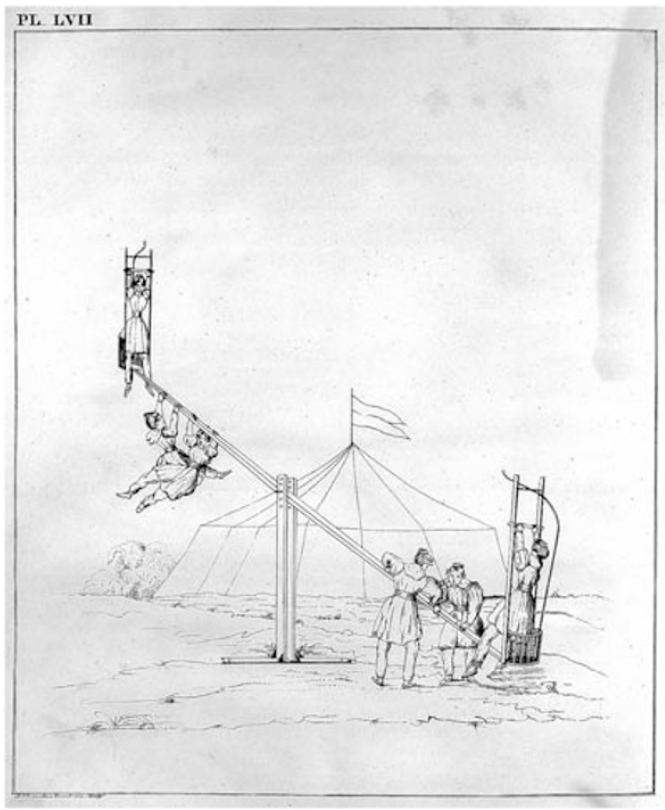

Figure 3 Gymnastic see-saw illustration taken from Delpech's De I'Orthomorphie par Rapport à l'éspèce Humaine, 1928.
There were three phases of treatment. First, the patients were placed supine on a hard bed for a long period to halt the progress of the condition. After a few weeks, they would be given extension treatment, alternating with further bed rest. There were different types of extension, some more forceful than others. Although controversial, forceful traction was used in France with disastrous results, often causing paralysis. By the 1830 s, it was banned by the Académie des Sciences. In England a more conservative approach prevailed. ${ }^{23}$

Maisonabe's bed used vertical or horizontal extension, with straps and belts, which could be shortened to increase the tension on the spine. ${ }^{7}$ Pravaz believed in moderate extension and advocated his 'balançoire orthopédique' a gentler system of weights and pulleys totally adjusted and controlled by the patient and with no force applied directly to the spine. ${ }^{24}$ Some methods were cumbersome involving a corset with a helmet to provide upward traction. JaladeLafond used his own extension chair and oscillating bed as he did not believe in permanent extension. ${ }^{6}$ Tavernier did not approve of extension beds and favoured the 'ceinture à levier' or lever-belt with inclination busk, designed by his associate, Hossard, claiming it provided with more flexibility with everyday tasks and allowed patients to lead as normal a life as possible. Tavernier's work was regarded as so important that it was translated into English in 1841 by Brewer. 5,25

Bouvier advocated the use of crutches to relieve weight on the feet. All the units recommended gymnastics to combat muscle weakness. After a few months and depending on the patient's progress, a regime of gymnastic exercises involving various pieces of apparatus, both in and outdoors would be administered between bed rest and traction sessions. This included swinging from poles and pulleys, games, using see-saws, Maypole dancing, balancing, swimming, walking in beautiful gardens and orchards (see Figures 3 and 4).

Although the use of water for treatment and recreation dates back to antiquity, by the end of the nineteenth

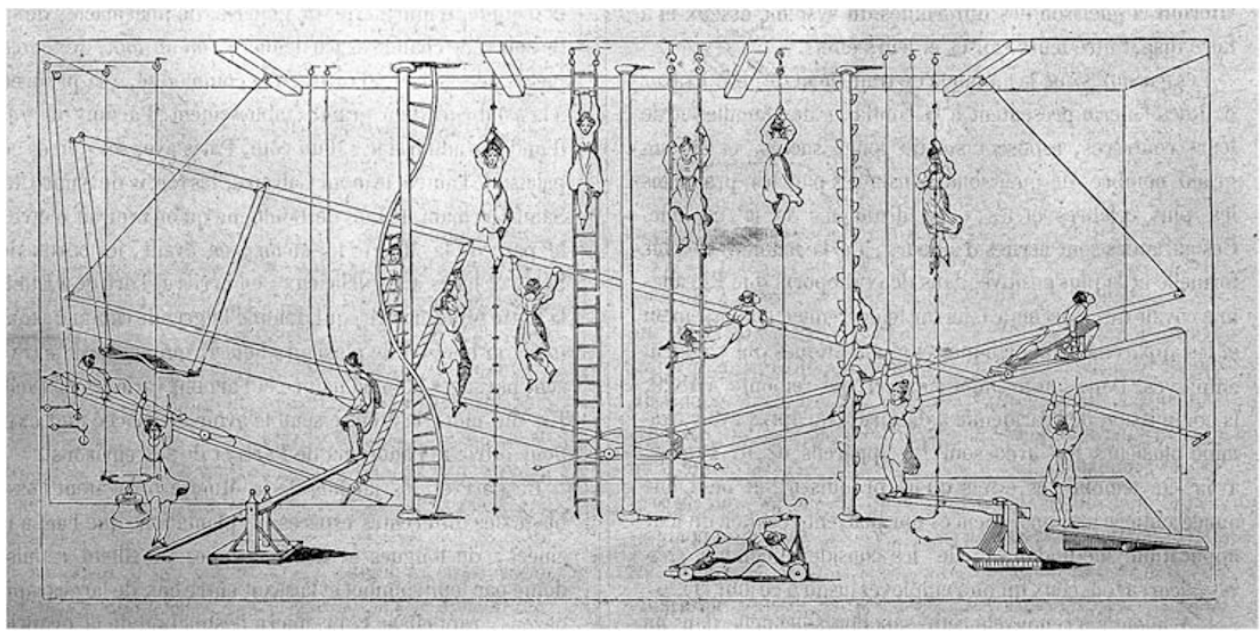

Figure 4 Diagram of exercises using the equipment available at Guérin's Paris Institute at the Château de la Muette, c.1837. Similar facilities would have been available at other units. 
century, various baths were frequently used for hydromechanical and hydro-pneumatic treatment purposes, manipulation and massage. ${ }^{1}$ Swimming was recognized from the outset as a beneficial exercise to support the whole body. Pravaz's swimming pool, which was heated by a boiler to stay at 'river' temperature, had a separate section that emulated the beneficial effect of sea water by adding salts and minerals to the water. Pravaz believed swimming helped to increase the lung capacity of the patients and enlarge their thorax. Surprisingly, despite the importance and emphasis placed on hydrotherapy, none of the units originated from spas.

Pravaz used a hyperbaric chamber to provide 'baths of compressed air' to treat his patients. This was particularly useful at the start of the treatment for patients who had difficulty performing the exercises. This passive therapy he claimed would increase the blood flow thereby encouraging tissue regeneration and restore the patients' appetite to help build up their strength. They used a $9-\mathrm{m}^{3}$ chamber into which condensed air would be pumped with the use of a vapour machine.

Pravaz also advocated cold baths and showers on the affected parts of the spine to activate the skin function and provide a tonic. He used electric and magnetic induction to stimulate the paralysed muscles. ${ }^{9}$

Treatment was not the prerogative of the medical profession. In the early part of the nineteenth century, 'orthopaedics' was a neglected discipline left in the hands of unqualified practitioners, instrument makers and poorly trained surgeons. These unqualified practitioners had been originally makers of armour and they subsequently turned their superb skills into producing the most beautiful appliances to treat deformity. ${ }^{19}$ Some worked independently, others worked in collaboration with qualified surgeons, making braces and other appliances for them. Spinal curvature in children was such a concern in France that every school had an extension bed. ${ }^{3}$

\section{The role of surgery}

Operations were mainly driven by warfare and limited to amputations. A few operations were carried out on the spine, mainly division of tendons to alleviate spinal curvature. Surgery was difficult because it was still in its infancy. Long operations were impossible because of the lack of anaesthesia, blood loss could not be replaced by transfusion and in the absence of antisepsis, infections were a dreaded and frequent complication. Nevertheless, surgery was performed in at least four of the units; Guérin at l'Institut du Château de la Muette performed a tenotomy in a case of torticollis. In Montpellier Delpech performed surgery albeit rarely, Bouvier performed tenotomy for the treatment of club foot and Pravaz performed reduction of luxations of the hip, and tenotomy for the treatment of club foot and torticollis.

\section{The authority of the founders of the private units}

After the Revolution, the newly formed 'Académie des Sciences' was a regulatory body with ultimate authority on medical practice. The surgeon's pre-eminent status was derived from several sources: their positions as professors at the universities, their appointments at municipal hospitals and their role as members of commissions appointed by the Académie des Sciences to assess medical equipment and the practice of medicine. This was a form of self-regulation and surgeons had to present their work to the academy twice a year and their findings were published. ${ }^{26}$ Recognition from the Académie des Sciences was the ultimate accolade and greatly enhanced the profile of an orthopaedic institute and this was not lost on Pravaz and Guérin when they received favourable comments on inspection of the units. Similarly, the protagonists were keen to present their equipment or methods of treatment to the commission to gain recognition among their patients and their peers and secure a licence to continue to practise. Conversely, failure to achieve endorsement from the commission had adverse consequences as experienced by Maisonabe, Guérin and Hossard. Maisonabe went into exile in Moldavia after his equipment was criticized and he was forced to admit its limitations in front of the commission. ${ }^{27,28}$ Guérin who was trained in medicine in Paris but had no surgical qualification, drew the wrath of the authorities for performing tenotomies and in 1848 an enquiry was set up to establish a line of demarcation between the developing field of orthopaedics and the recognized speciality of surgery. Bouvier and Jean François Malgaigne (1806-1865) criticized Guérin for using tenotomy too readily and eventually, having been discredited and his claims on tenotomy rejected by the commission, Guérin lost his appointment at the Hôpital des Enfants Malades, his institute closed down in 1849 and he was exiled to Belgium, his country of origin. ${ }^{29}$

Tavernier claimed that his 'ceinture à levier 'could yield results within a few months, rendering it more economical and attractive to patients and their families. His claims were much derided and a commission led by Bouvier and Guérin was set up to investigate his claims. Guérin accused Tavernier of misleading the commission with false reporting on cases presented by Mr Hossard. Interestingly, Guérin himself was using a slightly adapted version of the said belt to treat his own patients leading to Hossard's primacy counter claims. ${ }^{3}$

Despite the controversies, there is little doubt that the doctors and their units did help the patients and improve their condition. They drew their patients from the whole of France and abroad. There are drawings and plaster casts showing straightening of the spine with 'before and after treatment' representations. They received patients from eminent surgeons such as Dupuytren and Astley Cooper who endorsed their work.

\section{Why were seven private orthopaedic units opened to treat spinal deformity at the beginning of the nineteenth century?}

These units did not evolve gradually; their emergence after 1820 was a direct result of the new attitude prevailing after the French Revolution, encouraging freedom of ideas, 
innovation, discovery and meritocracy. What was the impact of the Revolution on the hospitals, the academies and the practitioners?

\section{The hospitals}

Gelfand has conducted a thorough review of the sociological background of medical reforms at the time of the French Revolution. The country changed from a despotic monarchical and hierarchical health system to a new medical era greatly influenced by the age of enlightenment and the importance of clinical examination and pathological anatomy. $^{30}$

Before the 1789 French Revolution, the medical hierarchy and administration were extremely complex. Although there were over 2000 hospitals, these were deplorable and overcrowding was endemic. ${ }^{12,26}$ Most hospitals were religious foundations, that is, 'de Dieu' (such as l'Hôtel Dieu). They were under state control, but were administered by nuns with no medical training, who often treated patients contrary to the wishes of the doctors. ${ }^{12}$ Gelfand showed that the hospitals were not involved in the teaching of medicine and actively resisted the presence of students. ${ }^{30}$ To achieve maximum efficiency and economy of scale, patients were segregated by age, gender and type of illness. In Paris, a central administration bureau was directing patients to specific hospitals such as women (La Pitié Salpêtrière), children (Hôpital des Enfants Malades), patients with venereal diseases (Hôpital du Midi), the insane (Saint Anne, La Salpêtrière and Bicêtre), those suffering from skin conditions (Saint Louis) and the elderly (La Salpêtrière and Bicêtre). ${ }^{31}$ Some hospitals were regarded as punitive institutions where patients could be confined to clear the street of vagabonds to shield the public at large from the distressing sight of disease and deformity. ${ }^{26}$

After the French Revolution, the Assemblée Constituante withdrew financing the hospitals. These became debt ridden and were eventually taken over by the local health authority or commune municipale.

The hospitals became medicalized. They became the centre of medical research and teaching and resident doctors enjoyed all the prestige associated with posts at general hospitals. Nepotism was still prevalent and in the midst of a very competitive and selective system, there were very few posts available for aspiring surgeons and many had to recourse to setting up their own institutes to pursue their researches. ${ }^{30}$

\section{The academies}

Before the French Revolution, medical practice in France was governed by the 'Académie Royale de Médecine', an intensely conservative and inward looking organisation that prevented progress, innovation or the development of original ideas. There are different schools of thought regarding the impact of the Revolution on the provision of healthcare in France. Ackernecht and Bynum believe that French medicine was a complete wilderness before and as a result of the Revolution great changes took place but Gelfand and Keel are of the view that the French medical scene was already changing but the Revolution accelerated the process. ${ }^{12,30,32,33}$

The French Revolution fuelled by a desire to abandon the 'old regime' of royal assent and nepotism and start anew brought turmoil to the scientific world. A 'laissez-faire' attitude prevailed to encourage all scientists regardless of their background and promote medical discovery and innovation. 'The career open to the talent' as per Napoleon's dictum. The myriad of regulatory bodies, medical schools and colleges were closed. After the dissolution of the institutions in 1793, including the 'Académie de Médecine', doctors benefited from freedom because no diplomas were required to practise. By 1794, reforms were put in place and three medical schools or Ecole de Santé were established in Paris, Strasbourg and Montpellier. ${ }^{26}$ Three years later these schools were integrated into the university system. Medicine became regulated once again with the setting up of the 'Institut de France', an umbrella organisation for various academies including l'Académie des Sciences. Under Napoleon, the role of the academies was purely advisory, but they were very powerful bodies. The 'Académie des Sciences' whose role was 'to report to Government on all matters pertaining to public health', appointed 'commissions' to assess medical practices and medical equipment. ${ }^{34}$ It is amazing that Napoleon himself as a member of the 'Institut de France', participated in meetings, insisting on awards being given to people of merit. Recognising the diversity of the equipment on offer and aware of the possible dangers as described by La Chaise and Jalade-Lafond, the Académie des Sciences appointed a commission to evaluate the therapeutic merit of each design to regulate the use of equipment in the treatment of spinal curvature.

\section{The practitioners}

Before the Revolution, doctors were apprenticed as part of their training, but there was a shortage of posts in the hospitals and positions were frequently assigned through patronage. These institutions were run by ignorant administrators and the staffs, comprised of usually untrained nuns, were in conflict with the doctors. The situation was so bad that Bourneville set up lay training schools for nurses. ${ }^{35}$ In addition, a surplus of doctors meant competition was fierce.

What was the effect of the Revolution on the practitioners? After the Revolution, there was freedom to practise anywhere but training was formalized with the designation of three medical schools, which eventually became part of the universities. The appointment of the doctors was no longer purely by nepotism but on merit and working in municipal hospitals gave them recognition. Although, the uniting of physicians and surgeons in 1794 gave surgeons recognition, they were still considered of a lower status than physicians, their origins being from trade and craft as opposed to a learned education. As a result, many could not secure the hospital appointment required to further their career and had to go into private practice. 


\section{The specialized hospitals}

Through force of personality and ability, a few doctors had established specialized departments within the hospitals such as Dupuytren who had a fracture clinic on the ground floor of the Hôtel Dieu. After the Revolution, specialisation greatly increased when doctors appointed to specialist hospitals developed their ideas. ${ }^{31}$

The opening of the seven orthopaedic units coincides with the Revolution. At that time, France was leading Europe in science and surgery. The whole philosophy of medicine changed and disease was localized to a given organ, no longer following the humoral theory of disease. This led to observation and experimentation and paved the way to specialisation.

All the private orthopaedic institutes' founders would have benefited from this change as they were classically trained and would have experienced hospital medicine and indeed most still held posts in the hospitals, often in a specialized unit. However, they could not develop the treatment of the patients in a municipal hospital because they had no authority. Each hospital was run by a male and female inspector, compulsorily resident and with absolute internal authority. They were frequently in conflict with the doctors. ${ }^{36}$ For this reason, the founders had to set up private institutes to control and define the type and duration of the treatment, choose their patients and observe them long term to delineate the natural history of the diseases. They secured their income and had the freedom to explore their interests further while retaining their involvement with the newly formed 'Académie des Sciences'.

These private institutes fulfilled an unmet need. This is remarkably similar to the development of public dispensaries in the United Kingdom.

\section{The legacy}

The units declined with the demise or death of their founders. Pravaz's son took over his institute in Lyon, Dr Victor Trinquier succeeded Delpech and a Dr Bertin took over from Tavernier but none of these had the expertize of the founders and the units soon closed down. The charisma, skill and reputation of the original founders were essential to maintain the reputation of these institutions. At their height, the units rapidly emerged and gained recognition as centres of excellence with acknowledgement by the profession and the patients. Although the units dealt predominantly with spinal deformities, other conditions were treated and cured. The role of these institutions in the development of orthopaedic surgery is crucial. Dupuytren, the foremost surgeon in Paris recognized their expertize and sent them patients. ${ }^{37}$ Bouvier worked in collaboration with Duchenne de Boulogne, a towering figure in neurology and research. ${ }^{2}$ Delpech is credited with the development of the tenotomy operation which was soon accepted worldwide and served as a cornerstone for the treatment of club foot and other deformities. ${ }^{3}$ The units, the practice of orthopaedics and the surgeons were victims of their own success. When they founded the units initially, the surgeons had been excluded from the municipal hospitals which would not make facilities available to them but as their expertize was recognized, experience in orthopaedics was seen to be essential and they were invited back into the hospitals which were now medicalized and very prestigious. Their success demonstrated that these specialities had to be included in the municipal hospitals if these were to maintain their place in the training of doctors and the treating of patients. As early as 1825, the Paris hospital administration had looked into the possibility of creating a special orthopaedic unit in one of the hospitals under the direction of Dr Peligot who had been part of the commission to evaluate the extension beds of Maisonabe and Jalade-Lafond, to control the use of this dangerous equipment, but it took more than 10 years for anything to happen. ${ }^{29}$ Bouvier is credited with being the first orthopaedic surgeon when he took charge of the first orthopaedic department at the hospital des enfants malades, after being appointed notably without examination. These pioneers' reputation stood the test of time and Le Vay, Singer and Underwood all acknowledge the primacy of Delpech and Bouvier as the founders of orthopaedics. 3,38

A similar situation pertained in London where the specialities were excluded from the voluntary hospitals, but despite opposition from the Royal College of Surgeons, both the specialists and the specialisation had to be invited back into the hospitals to set up specialized departments and with it came the decline of the private specialized hospitals that lacked the overall support from the universities. In London, the Royal Colleges insisted that a practitioner could not hold a twin appointment at a specialized hospital and a voluntary hospital. ${ }^{39}$

These pioneering units deserve special recognition for having been the first to provide residential integrated care to a group of patients suffering from spinal deformity (none of the traumatic spinal injury cases survived at the time), following a systematic regime of treatment. Not only was there provision for the treatment of spinal deformity, there was a holistic approach and Pravaz recognized that nutrition was important for the overall well-being of the patients. Despite this emphasis on treating 'the whole person' with exercise, swimming, baths, compressed air and the provision for education, the development of these units had little influence on the United Kingdom. The specialized units of Harrison and Verral had none of the ancillary facilities that gave a holistic approach to the treatment. The exercise at Malvern consisted of walking between the hills to fetch water and sport and gymnastics were largely confined to public schools and not part of rehabilitation until the First World War when wheelchair games were introduced at the Star and Garter Home in Richmond. ${ }^{1}$ This concept for the general care of the patient has been difficult to accept because the surgeons felt that their own operation was the critical element in treating the patient not the overall care and this fallacy persists to this day.

At the beginning of the twentieth century, Bradford and Lovett working in the United States believed that the imbalance of the muscles caused deformity and they advocated changes in posture and seating. ${ }^{40}$ They were the first to use plaster jackets applied while the patient was 
placed in suspension, but it was Francois Callot (1861-1944) of France who used forceful straightening to treat spinal deformity in many hospitals in Northern France, including the World renowned Berck orthopaedic institute. He applied pressure to the gibbus by means of pads inserted through the window left in the plaster. This method could be very successful in young patients. ${ }^{41}$

Today, treatment is by relaxing spastic muscles by means of exercise and posture, holding the corrected spine in place by using braces and when indicated carrying out surgical correction and fusion of the distorted spine to prevent the condition progressing.

Despite all the research into the biochemistry, the genetics and the anthropology of scoliosis and comparisons of identical twins, the situation with regard to the aetiology of the disease is as it was at the time of Hippocrates, unknown.

\section{Conclusion}

Eighty years after the emergence of the first French orthopaedic unit, the words of Tubby and Jones, leaders in the treatment of deformity, are the corner stone of modern spinal units.

\begin{abstract}
'It is impossible to separate the treatment into parts, and if the surgeon is not satisfied that the case is to be fully under his control for at least twelve months, he will consult his interest best by leaving it alone. His work does not cease with the operation but he becomes in reality the patients' physician for both mind and body. The three months' time limit at general hospitals must materially blight the prospects of paralytic subjects. They are neglected at home, and wander from one institution to another often the victims of conflicting theory and diverse practice. Successful hospital management of infantile spastic paralysis is not complete without an organised system of education carried out by specially trained nurses and the system must be of the visual and practical as opposed to the abstract type. In fact the time will come when scholastic institutes for the care of paralytic children of all classes will come and fill a most undesirable gap. ${ }^{\prime 42}$
\end{abstract}

\section{Conflict of interest}

The authors declare no conflict of interest.

\section{Acknowledgements}

We thank Dr Hugh Baron for his helpful advice. We are grateful to the Wellcome Library's Image Department for permitting to reproduce the illustrations.

\section{References}

1 Silver JR. History of the Treatment of Spinal Injuries. Kluwer Academic/Plenum Publishers: New York, 2003, pp 46.

2 Keith A. Menders of the Maimed. Oxford Medical Publications: London 1919, pp 95-194.
3 Le Vay D. The History of Orthopaedics. The Parthenon Publishing Group: New Jersey, 1990 (Chapter 4-National HistoriesFrance, pp 221-279; Chapter 6-National Histories-Switzerland pp 295-297; Chapter 24-Scoliosis, pp 529-545).

4 Pravaz C, Guérin J Institut Orthopédique de Paris, pour le Traitement des Difformités de la Taille et des Membres chez les personnes des deux sexes dirigés par MM. Les docteurs Pravaz et Jules Guérin à Passy près du Bois de Boulogne.

5 Tavernier Du Traitement des Difformités de la Taille par la Méthode d'Inclinaison (sans lit mécaniques) employé dans l'Institut Orthopédique Spécial du Docteur Tavernier à Paris et dans celui de M Hossard à Angers.

6 Jalade-Lafond $G$ Rechèrches pratiques sur les principales difformités du corps humain et sur les moyens d'y remédier. Paris 1827.

7 Maisonabe CA Journal Clinique sur les difformités et sur la mécanique et les instruments employés par la chirurgie en France Paris 1825.

8 Le Vay D. The History of Orthopaedics. The Parthenon Publishing Group: New Jersey, 1990, pp 251-252 (Chapter 4-National Histories-France).

9 Pravaz C Notice sur l'Institut Orthopédique et Pneumatique de Lyon Fondé par le docteur Charles Pravaz dirigé par le Docteur Pravaz Fils route des Etroits Près du Pont de la Mulatière Imprimerie D'aimé Vingtrinier: Lyon 1861.

10 Delpech J-M De l'Orthomorphie, par Rapport à l'Espèce Humaine; ou Recherches Anatomico-pathologiques sur les causes, les moyens de prévenir, ceux de guérir les principales difformités et sur les véritables fondements de l'art appelé orthopédique Atlas. Paris 1828.

11 Humbert F Notice sur les appareils et Machines Inventés par F Humbert. (Bar le Duc and Paris) 1834.

12 Ackerknecht EH. Medicine at the Paris Hospitals 1794-1848. The John Hopkins Press: Baltimore, 1967, pp 16, 19, 32, 177.

13 Organisation for Economic Co-operation and Development, History of the Château de la Muette OECD Headquarters, Paris. Available from http://www.oecd.org/document/63/0,3343, en_2649_201185_1956607_1_1_1_1,00.html (accessed 9 February 2009).

14 Glisson F Tractatus de Rachitide sive morbo puerilii (1650) English translation by P. Arnim (1651).

15 Deventer H Art of Midwifery, London 1716.

16 Bick EM. Source Book of Orthopaedics. The Williams \& Wilkins Company: Baltimore, 1948, pp 76.

17 David J-P Dissertation sur les effets du mouvement et du repos dans les maladies chirurgicales, A.F. Viret: Rouen, 1776.

18 Tronchin H Un médecin du XVIII ${ }^{\mathrm{e}}$ Siècle-Théodore Tronchin (1709-1781) Librairie Plon: Paris 1906.

19 Peltier LF. Orthopedics-A History and Iconography. Norman Publishing: San Francisco, 1993, pp 14, 195-207.

20 Tissot JC Gymnastique Médicinale et Chirurgicale translated by Elizabeth and Sidney Licht. Elizabeth Licht: New Haven, CT, 1987.

21 Werner JA L'Institut gymnastico-orthopédique de Dessau, son organisation et ses effets. BG Teubner: Dessau 1845.

22 Shaw J On the nature and treatment of the distortions to which the spine and the bones of the chest are subject Longman, Hurst Rees Orme Brown and Green: London, 1823, pp 231-232.

23 Weiner M-F, Silver JR. Paralysis as a result of traction for the treatment of scoliosis: a forgotten lesson from history. Spinal Cord 2009; 47: 429-434.

24 Pravaz C-G Méthode nouvelle pour le traitement des déviations de la colonne vertébrale. Paris 1827.

25 Dr Tavernier-Treatise on the treatment of deformities of the spine by the 'lever-belt with inclination busk' without extension beds or crutches. Translated by Brewer W. Simpkin, Marshall and Co: Stationers' Court, London 1842.

26 Brockliss L, Jones C. The Medical World of Early Modern France. Clarendon Press: Oxford, 1997, pp 579, 681, 720, 819.

27 Izac R De Rouergue en Moldavie notes sur Charles Maisonabe. In: Histoire des Sciences Médicales. Tome XII, No 1, 1978, (1779-1851) pp 451-458.

28 Gazette Médicale de Paris 1835 pp 405.

29 De Blécourt W, Usborne C. Cultural Approaches to the History of Medicine-Mediating Medicine in Early Modern and Modern Europe, Palgrave Macmillan, 2003, pp 155-156, 161. 
30 Gelfand T. Professionalizing Modern Medicine-Paris Surgeons and Medical Science and Institutions in the 18th Century, Greenwood Press: London, 1980, pp 10 and 92-114.

31 Weisz G. Divide and Conquer-A Comparative History of Medical Specialisation. Oxford University Press: Oxford, 2006, pp 15-18.

32 Bynum WF. Science and the Practice of Medicine in the Nineteenth Century. Cambridge University Press: Cambridge, 1994.

33 Keel O. The Politics of Health and the Institutionalisation of Clinical Practices in Europe in the Second Half of the Eighteenth Century in Bynum WF and Porter R. William Hunter and the Eighteenth-Century Medical World. Cambridge University Press: Cambridge, 1985 pp 207-256 (Chapter 8).

34 Shryock RH. The Development of Modern Medicine-An Interpretation of the Social and Scientific Factors Involved. The University of Wisconsin Press Ltd: London, 1936 p 107.
35 Rey R. The History of Pain. Harvard University Press: Cambridge Massachusetts, London England, 1995 p 189.

36 Baron JH. American Medical Students in 19th-Century Europe. Mount Sinai J Med 4 July 2005; 72: 270-273.

37 Caillard-Balonière AJ Sur les luxations originelles ou congénitales des fémurs. Thèse Faculté de Paris 1828.

38 Singer C, Ashworth Underwood E. A Short History of Medicine. Oxford University Press: London, 1962 p 658.

39 Cope Z. The History of the Royal College of Surgeons of England. Anthony Blond Ltd: London, 1959 p 72.

40 Lovett RW, Bradford EH Treatise on Orthopaedic Surgery, 2nd edition, William Wood and Co 1909.

41 Calot F Des moyens de guérir la bosse du mal de Pott., France Med 1896; 52.

42 Tubby AH, Jones R. Modern Methods in the Surgery of Paralyses. Macmillan and Co Ltd: London, 1903, p 237. 